\title{
Compartment syndrome of the leg after thyroid hormone withdrawal; two cases and a systematic review of the literature
}

Nicole M. van Veelen ${ }^{1 *}$ (D), Stefan Fischli ${ }^{2}$, Frank J.P. Beeres ${ }^{1}$, Timo Eisenhut ${ }^{1}$, Reto Babst ${ }^{1}$, Christoph Henzen ${ }^{2}$ and Björn-Christian Link'

\begin{abstract}
Background: Acute compartment syndrome is a rare complication of severe hypothyroidism. If the symptoms are not recognized promptly and treatment initiated immediately, there is a high risk of permanent damage. Only few other cases of compartment syndrome due to hypothyroidism have been published and the exact pathophysiological mechanism remains unknown.

Case presentations: A 59 year old male developed acute compartment syndrome of his right lower leg after thyroid hormone withdrawal prior to radioiodine remnant ablation after total thyroidectomy for follicular thyroid cancer. He underwent emergency fasciotomy of all four compartments of the lower leg. The muscle tissue in the anterior and lateral compartment was necrotic and was therefore excised. The second patient was a 62 year old female with Hashimoto's thyroiditis, who developed acute compartment syndrome of both lower legs after thyroid hormone withdrawal due to non-compliance. Emergency fasciotomy of all four compartments of both legs was performed. The muscle tissue was viable in all compartments.

Conclusion: Although compartment syndrome due to hypothyroidism is uncommon, it is a complication physicians should be aware of. The majority of reported cases are caused by an acute withdrawal of thyroid hormones and not by undetected hypothyroidism. No previous case of compartment syndrome caused by an iatrogenic hormone withdrawal in preparation for radioactive iodine has been published. However, as shown in this report, it may be beneficial to inform patients of this rare complication prior to hormone withdrawal in preparation for remnant ablation after thyroidectomy.
\end{abstract}

Keywords: Compartment syndrome, Myxedema, Thyroid gland, Hypothyroidism, Rhabdomyolysis

\section{Background}

Acute compartment syndrome can have a variety of causes. It is a well-known complication after vascular surgery or trauma. There have been few reports of cases caused by hypothyroidism [1]. To avoid delay in the initiation of appropriate treatment it is important for

\footnotetext{
* Correspondence: nicole.vanveelen@luks.ch

'Department of Orthopedic and Trauma Surgery, Luzerner Kantonsspital Luzern, P.O. Box, Spitalstrasse, 6000 Lucerne, Switzerland

Full list of author information is available at the end of the article
}

emergency physicians to be aware of this rare complication. The pathogenesis of compartment syndrome due to hypothyroidism remains unknown. We present two cases of this unusual cause and review the relevant literature.

\section{Clinical presentation}

\section{Patient 1}

A 59 year old male patient presented to the emergency department with pain in his right lower extremity. $\mathrm{He}$

(c) The Author(s). 2020 Open Access This article is licensed under a Creative Commons Attribution 4.0 International License, which permits use, sharing, adaptation, distribution and reproduction in any medium or format, as long as you give appropriate credit to the original author(s) and the source, provide a link to the Creative Commons licence, and indicate if changes were made. The images or other third party material in this article are included in the article's Creative Commons licence, unless indicated otherwise in a credit line to the material. If material is not included in the article's Creative Commons licence and your intended use is not permitted by statutory regulation or exceeds the permitted use, you will need to obtain permission directly from the copyright holder. To view a copy of this licence, visit http://creativecommons.org/licenses/by/4.0/ The Creative Commons Public Domain Dedication waiver (http://creativecommons.org/publicdomain/zero/1.0/) applies to the data made available in this article, unless otherwise stated in a credit line to the data. 
first noticed the pain 2 days prior to presentation. The patient denied any trauma to the leg previous to the pain onset. On the day the pain started, the patient had been discharged from another hospital where he had received radioactive iodine for remnant ablation after thyroidectomy for follicular thyroid cancer with a postoperative TNM-stage of pT3apN0 (0/1). For this reason, the thyroid substitution therapy (triiodothyronine $20 \mu \mathrm{g}$ twice daily), which was initially started after thyroidectomy 4 weeks earlier, had been paused for 3 weeks. Upon discharge the substitution therapy was initiated again. The patient's family reported a change of character and unusual behaviour since pausing the thyroid substitution therapy. Review of his medical history showed arterial hypertension, which was treated with an ACE-blocker. Furthermore, the laboratory workup prior to thyroidectomy showed elevated anti-thyroid peroxidase antibodies (5734 U/ml) suggesting Hashimoto's thyroiditis.

Physical examination demonstrated erythema and swelling of the right lower leg. Both Meyer and Hohmann signs where positive, however, Payr sign was negative. Laboratory values were as follows: Leucocytes 15.0 G/l (2.6-7.8), D-Dimer $1555 \mathrm{ng} / \mathrm{ml} \mathrm{(<500),} \mathrm{Creatinine}$ $109 \mu \mathrm{mol} / \mathrm{L}$ (44-97), lactate dehydrogenase (LDH) 3051 $\mathrm{U} / \mathrm{L}(<250)$, c-reactive protein (CRP) $109 \mathrm{mg} / \mathrm{L}(<5)$, creatinine kinase (CK) 71,971 U/L (<170), thyroid stimulating hormone (TSH) $88.5 \mathrm{mU} / \mathrm{L} \quad(0.27-4.2)$, free thyroxine $0.88 \mathrm{pmol} / \mathrm{L} \quad(12-22)$, sodium $136 \mathrm{mmol} / \mathrm{l}$ (135-148). Besides the change of behaviour and character there were no other signs of myxedema coma such as hypothermia or cardiorespiratory symptoms. The massive elevation of CK was considered to be caused by rhabdomyolysis due to severe hypothyroid myopathy and was treated with intravenous hydration. Deep venous thrombosis was suspected due to the elevated DDimer and anticoagulation was initiated. An ultrasound was scheduled for the following day, which then ruled out a deep venous thrombosis. The patient developed a low-grade fever $\left(38.3^{\circ} \mathrm{Celsius}\right)$ and laboratory parameters for infection continued to rise (CRP $159 \mathrm{mg} / \mathrm{L}$ ). Therapeutic anticoagulation was stopped and empiric antibiotic therapy with amoxicillin/clavulanic acid was started, as it was suspected that the symptoms were caused by an erysipelas. The next day the patient showed a loss of dorsiflexion of the foot and reduced sensibility in the area supplied by the superficial and deep peroneal nerve. The measured pressure in the anterior compartment was $95 \mathrm{mmHg}$ and in the peroneal compartment was $120 \mathrm{mmHg}$. Emergency fasciotomy of all four compartments of the right lower leg was performed. The muscle tissue in the peroneal and anterior compartments was necrotic (Fig. 1), showed no contractility, and was therefore excised. The muscles in the remaining compartments were healthy and viable. There was no

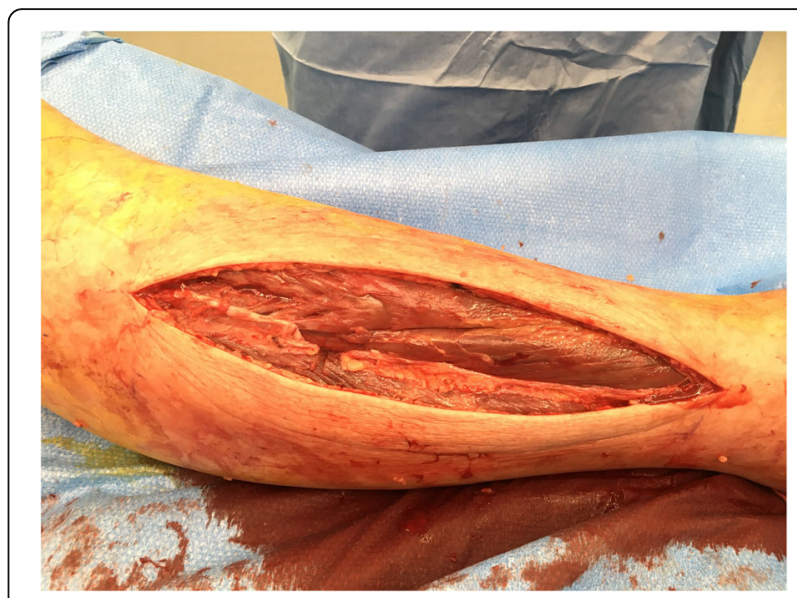

Fig. 1 Necrotic tissue in anterior and lateral compartment

sign of infection and the empiric antibiotic therapy was stopped. After surgery the patient was admitted to the intensive care unit for the initial postoperative care. The CK levels quickly decreased, renal function and electrolyte levels remained normal. Peroral levothyroxine treatment was continued leading to a steady fall of the TSH levels. Delayed primary closure of the fasciotomy wounds was achieved after 3 days and hindfoot arthrodesis was performed shortly after to treat the foot drop. The patient was discharged to a rehabilitation center for gait training. He is currently ambulatory with the aid of crutches.

\section{Patient 2}

A 62 year old female was referred to our emergency department by her family doctor. Over the previous days she had been feeling weak with progressive difficulty walking. Additionally, she had noticed swelling of her tongue and face as well as unusual obstipation and a "croaky" voice.

A review of her medical history was significant for diabetes mellitus type 2 (treated with metformin), Hashimoto hypothyroidism substituted with levothyroxine $(125 \mu \mathrm{g} /$ day), thalassemia minor, hypertension (treated with an ACE-blocker) and chronic obstructive pulmonary disease (treated with Salmeterol) with a continued nicotine consumption (60 pack years). Over a month prior to her presentation, she had ceased taking all her medication, as her prescription had run out.

Physical examination showed a pulse of 61 beats per minute, blood pressure of $138 / 77 \mathrm{mmHg}$ and oxygen saturation of $80 \%$ on room air, $94 \%$ with 21 O2/minute. There were no pathologic cardiac findings. Her expiration was slightly prolonged and her face was puffy. Laboratory examinations revealed a potassium of 5.6 $\mathrm{mmol} / \mathrm{L}$ (3.4-4.5), sodium $134 \mathrm{mmol} / \mathrm{l}$ (135-148) serum glucose $10.4 \mathrm{mmol} / \mathrm{L}$ (3.9-5.8), HbA1c 8.6\% (4.8-5.9), 
CK 4144 U/L $(<170), \mathrm{TSH}>100 \mathrm{mU} / \mathrm{L}(0.27-4.2)$ and a free thyroxine of $0.5 \mathrm{pmol} / \mathrm{L}$ (12-22). The patient was admitted to the medical ward and levothyroxine substitution combined with hydrocortisone was started. Two days later she presented with progressively decreasing vigilance and global respiratory insufficiency due to chronic obstructive pulmonary disease, myxedema with alveolar hypoventilation and heart failure. The chest $x$ ray showed left-sided pleural effusion. The patient was transferred to the intensive care unit for further therapy including non-invasive ventilation, inotropic therapy with dobutamine and intravenous substitution of thyroxine and triiodothyronine $(100 \mu \mathrm{g} /$ day and $20 \mu \mathrm{g} /$ day respectively). The following day the patient complained of pain in both of her calves. On clinical examination the soft tissue of the right lower limb was tense and pain was exacerbated by passive stretching of the muscle. Venous Doppler ultrasound was negative for a thrombotic process. Compartment pressure was elevated both in the right anterior $(70 \mathrm{mmHg})$ and in the peroneal $(60$ $\mathrm{mmHg}$ ) compartments with a median arterial pressure of $80 \mathrm{mmHg}$. Because the intraoperative pressure measurement also showed elevated pressures in the left lower leg compartments $(30-40 \mathrm{mmHg}$ ) fasciotomy was performed in all 4 muscle compartments of both lower legs. The muscle tissue in the anterior compartment on the right side was slightly pale. All other compartments showed viable muscles with good contractility. Delayed primary closure of the wounds was achieved within 4 days with full muscle recovery. The patient was discharged to a psychiatric hospital 2 weeks after fasciotomy due to a psychosis, which was most likely triggered by the myxedema.

\section{Discussion and conclusions}

Acute compartment syndrome is a well-known problem after trauma or vascular surgery. Other less frequent causes include snake bites, nephrotic syndrome [1], extravasation of contrast medium [2], and as demonstrated in this and few previous case reports severe hypothyroidism [3]. Compartment syndrome is defined as an increased pressure within a closed compartment that causes a disruption of the perfusion of tissue within. If the pressure in the compartment is not released, permanent damage to the soft tissue within can occur, which in turn can cause loss of function and potentially even the loss of the affected limb $[1,2]$. The increase in pressure can be due to conditions which either increase the content or decrease the size of the compartment $[2,4]$.

To find other cases of compartment syndrome associated with hypothyroidism we performed a Pubmed-search using the combined keywords "hypothyroid" and "compartment syndrome" working with PRISMA guidelines [5] (Fig. 2). Only publications in English with an available

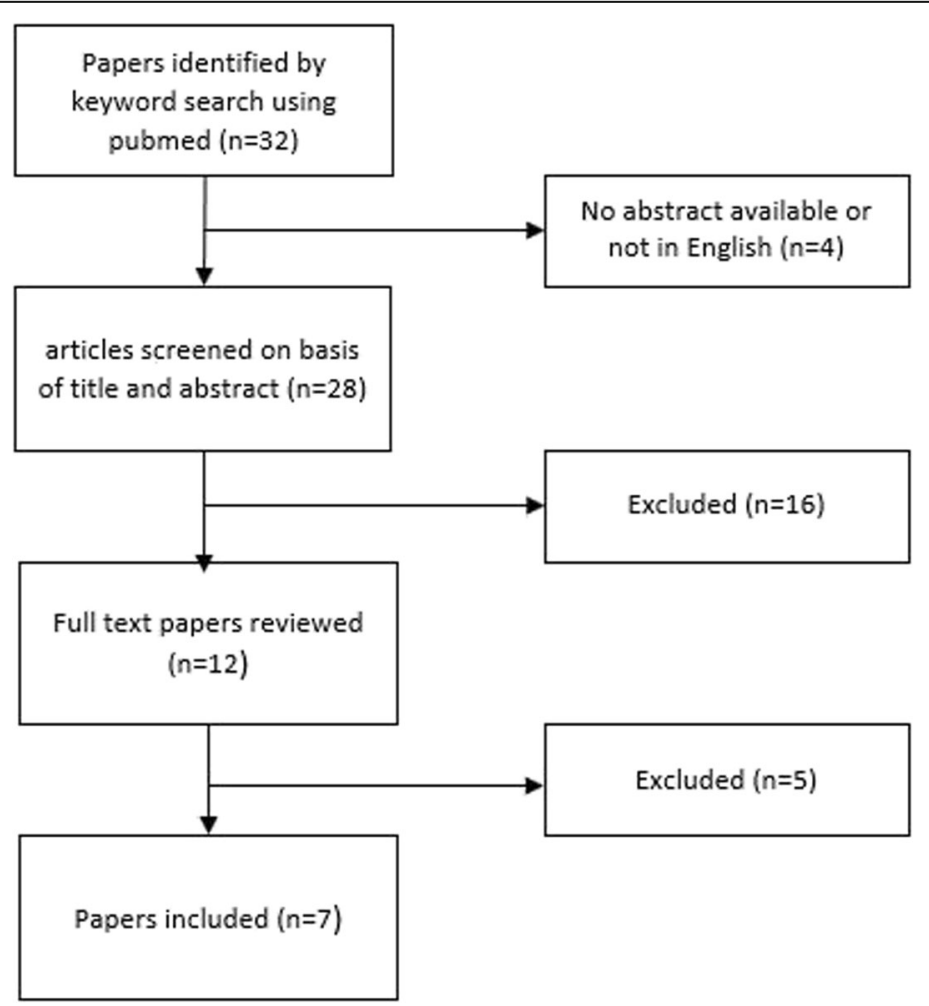

Fig. 2 Flow diagram of study selection 
abstract reporting on compartment syndrome with no other cause besides hypothyroidism were included. Reports involving children under 18 years of age where excluded.

We found five other reported cases of compartment syndrome due to hypothyroidism, with the first one published in 1993. (Table 1) An additional case was reported in a patient that had concomitant adrenal insufficiency and one case after coronary artery bypass grafting in a patient with undiagnosed hypothyroidism. We also found one literature review on hypothyroid myopathy [3], but no specific data to compartment syndrome. None of the previously published cases were caused by iatrogenic hormone withdrawal in preparation for radioiodine remnant ablation after thyroidectomy, making our case the first.

The exact pathomechanism of compartment syndrome in hypothyroidism is still unknown. Rhabdomyolysis caused by hypothyroidism is a rare condition and is usually triggered or exacerbated by renal or adrenal failure, by excessive exercise or by the consumption of lipidlowering drugs or alcohol. The pathogenesis remains discussed with possible causes being a reversible defect in glycogenolysis and low mitochondrial enzyme activity leading to mitochondrial metabolism impairment [3]. The edema caused by muscle necrosis could lead to an increase in compartment content resulting in compartment syndrome [13]. However rhabdomyolysis is also a common complication of compartment syndrome [14]. It is therefore impossible to determine whether the compartment syndrome in patients with hypothyroidism is caused by rhabdomyolysis or whether, analogue to compartment syndrome after trauma [14], rhabdomyolysis is a complication of compartment syndrome. As neither of our patients had any risk factors for rhabdomyolysis, such as consumption of lipid-lowering drugs, it seems more likely that rhabdomyolysis was a result of the compartment syndrome.

Other forms of myopathy caused by hypothyroidism include Hoffmann's syndrome and Koche-Debre'-semelaigne syndrome. These syndromes describes the presence of hypothyroidism with muscle weakness and pseudohypertrophy in adults [15] and children [3] respectively. The Calf muscles (gastrocnemius) are almost always involved [3]. The etiology of the muscle enlargement remains controversial [16]. It has been suggested that it is due to an increase in connective tissue as well as size and number of muscle fibers [15]. Other papers

Table 1 Review of literature

\begin{tabular}{|c|c|c|c|c|c|c|}
\hline & Year & $\begin{array}{l}\text { Age, } \\
\text { gender }\end{array}$ & Cause of hypothyroidism & $\begin{array}{l}\text { Laboratory } \\
\text { values }\end{array}$ & $\begin{array}{l}\text { Compartment pressure }(\mathrm{mmHg}) \text { and } \\
\text { viability }\end{array}$ & $\begin{array}{l}\text { Unilateral vs } \\
\text { bilateral }\end{array}$ \\
\hline \multirow{2}{*}{$\begin{array}{l}\text { Thacker A. } \\
{[6]}\end{array}$} & \multirow[t]{2}{*}{1993} & \multirow[t]{2}{*}{40 male } & \multirow[t]{2}{*}{ Not mentioned, antibodies normal } & CK? & Pressure not mentioned & \multirow[t]{2}{*}{ bilateral } \\
\hline & & & & $\begin{array}{l}\text { TSH } 118 \\
\mathrm{mU} / \mathrm{l}\end{array}$ & Anterior Compartment released & \\
\hline \multirow[t]{4}{*}{ Hsu S. [7] } & \multirow[t]{4}{*}{1995} & \multirow[t]{4}{*}{$\begin{array}{l}33 \\
\text { female }\end{array}$} & \multirow[t]{4}{*}{ Undetected Hashimoto } & $\begin{array}{l}\text { CK } 11 ' 319 \mathrm{U} / \mathrm{I} \\
\text { I }\end{array}$ & Lateral: 65 (necrotic) & \multirow[t]{4}{*}{ unilateral } \\
\hline & & & & \multirow{3}{*}{$\begin{array}{l}\text { TSH } 87 \mathrm{mU} / \\
\mathrm{mL}\end{array}$} & Anterior: 124 & \\
\hline & & & & & Superf. dorsal: 24 & \\
\hline & & & & & Deep dorsal: 62 & \\
\hline \multirow[t]{2}{*}{ Mills J [8] } & \multirow[t]{2}{*}{2010} & \multirow[t]{2}{*}{72 male } & \multirow[t]{2}{*}{$\begin{array}{l}\text { Undetected hypothyroidism, aetiology } \\
\text { not mentioned }\end{array}$} & $\begin{array}{l}\text { CK } \\
\text { unknown }\end{array}$ & \multirow[t]{2}{*}{ Anterior: 75 mmHg (necrotic) } & \multirow[t]{2}{*}{ bilateral } \\
\hline & & & & $\begin{array}{l}\text { TSH } 42.3 \\
\mathrm{mU} / \mathrm{l}\end{array}$ & & \\
\hline \multirow[t]{2}{*}{ Muir P. [9] } & \multirow[t]{2}{*}{2012} & \multirow[t]{2}{*}{22 male } & Undetected Hashimoto & $\begin{array}{l}\text { CK }>25^{\prime} 000 \\
U / I\end{array}$ & \multirow[t]{2}{*}{$\begin{array}{l}\text { Pressure not messured (MRI shows } \\
\text { necrosis of M. tib. Ant.) }\end{array}$} & \multirow[t]{2}{*}{ bilateral } \\
\hline & & & + adrenal insufficiency & $\begin{array}{l}\text { TSH } \\
\text { unknown }\end{array}$ & & \\
\hline \multirow[t]{2}{*}{$\begin{array}{l}\text { Hariri N. } \\
{[10]}\end{array}$} & \multirow[t]{2}{*}{2014} & \multirow[t]{2}{*}{60 male } & Medication non-compliance & $\begin{array}{l}\text { CK } 68,000 \mathrm{U} / \\
\text { । }\end{array}$ & Anterior: 75 (necrotic) & \multirow[t]{2}{*}{ Bilateral } \\
\hline & & & $\begin{array}{l}\text { Aetiology of Hypothyroidism not } \\
\text { mentioned }\end{array}$ & $\begin{array}{l}\text { TSH } 176 \\
\mathrm{mU} / \mathrm{L}\end{array}$ & Lat. \&dorsal: 10-15 & \\
\hline \multirow{2}{*}{$\begin{array}{l}\text { Modi A. } \\
{[11]}\end{array}$} & \multirow[t]{2}{*}{2016} & \multirow{2}{*}{$\begin{array}{l}42 \\
\text { female }\end{array}$} & Hashimoto & CK $1854 \mathrm{U} / \mathrm{L}$ & Lateral: 142 & \multirow[t]{2}{*}{ unilateral } \\
\hline & & & Medication non-compliance & $\begin{array}{l}\text { TSH } 147 \\
\mathrm{mU} / \mathrm{L}\end{array}$ & Anterior: 96 & \\
\hline \multirow{2}{*}{$\begin{array}{l}\text { Musielak M. } \\
{[12]}\end{array}$} & \multirow[t]{2}{*}{2016} & \multirow{2}{*}{$\begin{array}{l}49 \\
\text { female }\end{array}$} & Medication non-compliance & CK 13977 U/I & Pressure not mentioned & \multirow{2}{*}{$\begin{array}{l}\text { Bilateral upper and } \\
\text { lower extremities }\end{array}$} \\
\hline & & & $\begin{array}{l}\text { Aetiology of Hypothyroidism not } \\
\text { mentioned }\end{array}$ & $\begin{array}{l}\text { TSH } 164 \\
\mathrm{mU} / \mathrm{L}\end{array}$ & Anterior and lateral necrotic & \\
\hline
\end{tabular}


have described glycosaminoglycan deposition and increased extravasation of plasma protein in the interstitial space coupled with impaired compensatory lymph flow and protein return rate [7]. These findings suggest an increase in the volume of the compartment contents [7] which could lead to compartment syndrome. However, as mentioned above, Hoffmann's syndrome usually involves the gastrocnemius, whereas in our cases and all but one of the other case reports [6, 8-12] we found, the anterior and lateral muscles were predominantly involved. A connection between Hoffman's syndrome and compartment syndrome therefore seems unlikely. We found no apparent reason for the anterior and lateral compartments to be affected more than other compartments. A larger collection of patients would be needed to be able to further investigate this observation.

Three of the previously published cases $[7,9,11]$ and both cases described in this report had Hashimoto's thyroiditis. A link between hypothyroidism due to autoimmune thyroiditis and the occurrence of compartment syndrome therefore seems possible. However, we found no literature elaborating this possible connection. Furthermore, the antibodies were normal in the first case published [6], ruling out autoimmune thyroiditis in this patient. Although to our knowledge it has not yet been discussed, the majority of cases (three of the previously published cases plus our two cases) of compartment syndrome due to hypothyroidism are caused by a withdrawal of thyroid hormones and not by undetected and untreated hypothyroidism. This raises the question whether patients undergoing hormone withdrawal are at a higher risk of compartment syndrome than those with undetected hypothyroidism. However, the amount of available literature is too limited to draw reliable conclusions.

In summary, although compartment syndrome due to hypothyroidism is uncommon, it is a complication both endocrinologists and emergency physicians should be aware. For if it is missed, the consequences for the patient can be devastating.

The exact pathophysiological mechanism causing this rare condition still needs to be elucidated. Withdrawal of thyroid hormones might play a role in triggering the development of compartment syndrome, but evidence is sparse. Further, autoimmune thyroiditis could influence the development of compartment syndrome, however literature supporting this presumption is lacking. In patients with known hypothyroidism presenting with leg pain, compartment syndrome should be included in the differential diagnosis and the appropriate investigations performed. Moreover, it may be beneficial to inform patients of this rare complication prior to hormone withdrawal in preparation for remnant ablation after thyroidectomy.

\section{Abbreviations}

ACE: Angiotensin converting hormone; LDH: Lactate dehydrogenase; CRP: Creactive protein; $\mathrm{CK}$ : Creatinine kinase; TSH: Thyroid stimulating hormone; HbA1c: Hemoglobin A1c

\section{Acknowledgements}

Not applicable.

Authors' contributions

NW and TE analysed and interpreted the patient data. NW, BL, RB and SF were involved in the patient care. NW conducted the literature review and wrote the manuscript. $\mathrm{BL}, \mathrm{RB}, \mathrm{FB}, \mathrm{SF}$ and $\mathrm{CH}$ proof read the manuscript and critically revised it for content. All authors read and approved the final manuscript.

\section{Funding}

There was no funding provided for this report.

Availability of data and materials

All data generated or analysed during this study are included in this published article.

Ethics approval and consent to participate Not applicable.

\section{Consent for publication}

The patients signed an informed consent form, permitting the use of their medical data for research purposes including publication.

\section{Competing interests}

The authors declare that they have no competing interests.

\section{Author details}

${ }^{1}$ Department of Orthopedic and Trauma Surgery, Luzerner Kantonsspital Luzern, P.O. Box, Spitalstrasse, 6000 Lucerne, Switzerland. ${ }^{2}$ Department of Endocrinology and Diabetes, Luzerner Kantonsspital Luzern, P.O. Box, Spitalstrasse, 6000 Lucerne, Switzerland.

Received: 9 January 2020 Accepted: 21 May 2020

Published online: 05 June 2020

\section{References}

1. Taylor RM, Sullivan MP, Mehta S. Acute compartment syndrome: obtaining diagnosis, providing treatment, and minimizing medicolegal risk. Curr Rev Musculoskelet Med. 2012;5(3):206-13.

2. van Veelen NM, Link BC, Donner G, Babst R, Beeres FJP. Compartment syndrome of the forearm caused by contrast medium extravasation: a case report and review of the literature. Clin Imaging. 2020;61:58-61.

3. Sindoni A, Rodolico C, Pappalardo MA, Portaro S, Benvenga S. Hypothyroid myopathy: a peculiar clinical presentation of thyroid failure. Review of the literature. Rev Endocr Metab Disord. 2016;17(4):499-519.

4. Balogh ZJ, Butcher NE. Compartment syndromes from head to toe. Crit Care Med. 2010;38(9 Suppl):S445-51.

5. Liberati A, Altman DG, Tetzlaff J, Mulrow C, Gotzsche PC, loannidis JP, et al. The PRISMA statement for reporting systematic reviews and meta-analyses of studies that evaluate health care interventions: explanation and elaboration. PLoS Med. 2009:6(7):e1000100.

6. Thacker AK, Agrawal D, Sarkari NB. Bilateral anterior tibial compartment syndrome in association with hypothyroidism. Postgrad Med J. 1993;69(817): $881-3$.

7. Hsu SI, Thadhani RI, Daniels GH. Acute compartment syndrome in a hypothyroid patient. Thyroid. 1995;5(4):305-8.

8. Mills J, Pretorius V, Lording T, Hardikar A, Murton M. Bilateral anterior compartment syndrome after routine coronary artery bypass surgery and severe hypothyroidism. Ann Thorac Surg. 2010;90(4):1338-40.

9. Muir P, Choe MS, Croxson MS. Rapid development of anterotibial compartment syndrome and rhabdomyolysis in a patient with primary hypothyroidism and adrenal insufficiency. Thyroid. 2012;22(6):651-3.

10. Hariri N, Mousa A, Abu-Halimah S, Richmond B. Bilateral lower extremity anterior compartment syndrome in a severely hypothyroid patient. Am Surg. 2014;80(12):E337-8. 
11. Modi A, Amin H, Salzman M, Morgan F. Acute compartment syndrome caused by uncontrolled hypothyroidism. Am J Emerg Med. 2017;35(6):937 e5-e6.

12. Musielak MC, Chae JH. Hypothyroid-induced acute compartment syndrome in all extremities. J Surgical Case Rep. 2016;2016(12).

13. Ramadhan A, Schondorf $R$, Tamilia M. Rhabdomyolysis and peroneal nerve compression associated with thyroid hormone withdrawal in the setting of remnant ablation: review of the literature. Endocrine Pract. 2011;17(4):629-35.

14. Tsai WH, Huang ST, Liu WC, Chen LW, Yang KC, Hsu KC, et al. High risk of rhabdomyolysis and acute kidney injury after traumatic limb compartment syndrome. Ann Plast Surg. 2015;74(Suppl 2):S158-61.

15. Tuncel D, Cetinkaya A, Kaya B, Gokce M. Hoffmann's syndrome: a case report. Med Principles Pract. 2008;17(4):346-8.

16. Praveen K, Aslam S, Dutta T. HoffMann's syndrome: A rare neurological presentation of hypothyroidism. Int J Nutr Pharmacol Neurol Dis. 2011;1(2):201.

\section{Publisher's Note}

Springer Nature remains neutral with regard to jurisdictional claims in published maps and institutional affiliations.

Ready to submit your research? Choose BMC and benefit from:

- fast, convenient online submission

- thorough peer review by experienced researchers in your field

- rapid publication on acceptance

- support for research data, including large and complex data types

- gold Open Access which fosters wider collaboration and increased citations

- maximum visibility for your research: over $100 \mathrm{M}$ website views per year

At BMC, research is always in progress.

Learn more biomedcentral.com/submissions 